Cletus C. Coughlin is a vice president and associate director of research and Patricia S. Pollard is an economist and research officer at the Federal Reserve Bank of St. Louis. Heidi L. Beyer provided research assistance.

\section{State Exports and the Asian Crisis}

\author{
Cletus C. Coughlin \\ and Patricia S. Pollard
}

\section{INTRODUCTION}

D eal merchandise exports from the United States to East Asia fell by 12 percent during 1998 as the Asian crisis reduced demand in the region. ${ }^{1}$ These markets accounted for about 30 percent of U.S. exports prior to the crisis. Given this market share, the 12-percent drop in merchandise exports to East Asia would have resulted in a 4-percent drop in total U.S. merchandise exports, absent any changes in export sales elsewhere Because merchandise exports account for 10 percent of U.S. output, the 4-percent decline in exports would have resulted in a 0.4-percent decline in U.S. output. This decline did not occur because exports to the rest of the world increased and, more importantly, strong U.S. domestic demand offset the negative effects of the trade shock.

Despite the overall benign effect on the U.S. economy, the Asian crisis produced numerous microeconomic effects. In a recent article in this Review, Pollard and Coughlin (1999) estimated the effects of the decline in exports to East Asia on an industry-by-industry basis. ${ }^{2}$ Exports to East Asia fell during 1998 for 25 of the 26 industries studied. These declines ranged from 35 percent for the metallic ores and concentrates industry to 3 percent for the food and kindred products industry. The one industry whose exports to East Asia rose was the transportation industry, driven primarily by increases in aircraft exports to China and Taiwan.

In the absence of offsetting effects, the relevance of these declines in exports for the sales of each industry depended on the importance of East Asian markets for each industry's production. Taking account of this, Pollard and Coughlin (1999) cal culated that the nonelectrical machinery industry was the one affected most adversely by the decline in exports to East Asia. The growth rate of gross output in that industry would have been 1.8 percentage points higher if exports to East Asia had not declined. Of those industries whose exports to East Asia fell during 1998, the printing and publishing industry was affected the least, primarily because East Asia was not an important outlet for its production.

Because industry composition varies across states, the different export effects across industries suggest that individual states may have been affected to varying degrees by the Asian crisis. Furthermore, the geographic pattern of trade varies across states indicating that those with a high proportion of exports going to East Asia were more likely to have been affected by the crisis than others. Although the effects of the Asian crisis on specific states have been addressed in a number of studies, to date, no comprehensive study of the export effects across states has been published. ${ }^{3}$ One study providing a state-by-state analysis was released during early 1998 by the Department of Commerce and the Treasury Department (1998). The goal of that study, however, was to predict the states that were most likely to be affected, rather than to calculate the actual effects.

This article provides an additional perspective on the microeconomic effects of the Asian crisis focusing on manufacturing sectors of individual states. We begin with an overview of state-level manufacturing exports. Next, we examine the changes across states in manufacturing exports to East Asia. We then examine the importance of the East Asian markets to each state. Combining estimates of the change in a state's exports to East Asia with the assessment of the importance of these exports to the manufacturing sector allows us to generate an estimate of the effect of the trade shock on state manufacturing output. The countries and industries driving these results also are highlighted.

The Asian crisis affected the U.S. economy through several channels, most notably, a direct trade effect and indirect commodity price and interest

\footnotetext{
${ }^{1}$ In this article, East Asia is defined as China, Hong Kong, Indonesia, Japan, Korea, Malaysia, Philippines, Singapore, Taiwan, and Thailand. These 10 countries are the ones most directly associated with the Asian crisis. Focusing attention on a subset of the seven most affected countries does not change the nature of our results.

${ }^{2}$ A microeconomic analysis of the Asian crisis focusing on firm-level effects can be found in the article by Emmons and Schmid in this issue of the Review.

${ }^{3}$ For examples of analyses focusing on specific states, see Valletta (1998) for a study of California, Oregon, and Washington; Duca et al. (1998) for a study of Texas; and Gazel and Lamb (1998) for a study of Colorado, Kansas, Missouri, Nebraska, New Mexico, Oklahoma, and Wyoming.
} 
Table 1

State Exports of Manufactured Goods (1997)

Total (millions of 1996 dollars)

Per Capita (1996 dollars)

\begin{tabular}{|c|c|c|c|c|}
\hline State & East Asia (Rank) & All Countries (Rank) & East Asia (Rank) & All Countries (Rank) \\
\hline California & $\$ 49,333(1)$ & $\$ 104,726(1)$ & $\$ 1,533(3)$ & $\$ 3,254(5)$ \\
\hline Texas & $15,327(2)$ & $80,178(2)$ & $791(9)$ & $4,136(3)$ \\
\hline Washington & $14,418(3)$ & $31,996(5)$ & $2,568(1)$ & $5,699(2)$ \\
\hline New York & $7,697(4)$ & $38,881(3)$ & $424(24)$ & $2,143(17)$ \\
\hline Arizona & $6,329(5)$ & $14,466(13)$ & $1,390(4)$ & $3,177(6)$ \\
\hline Illinois & $6,259(6)$ & $28,570(6)$ & $522(18)$ & $2,383(11)$ \\
\hline Massachusetts & $5,385(7)$ & $17,454(9)$ & $881(7)$ & $2,855(8)$ \\
\hline Ohio & $4,655(8)$ & $26,286(8)$ & $416(25)$ & $2,348(12)$ \\
\hline Oregon & $4,086(9)$ & $8,294(21)$ & $1,260(5)$ & $2,557(9)$ \\
\hline Pennsylvania & $3,754(10)$ & $17,392(10)$ & $313(35)$ & $1,448(30)$ \\
\hline North Carolina & $3,218(11)$ & $16,789(11)$ & $433(22)$ & 2,259 (13) \\
\hline Minnesota & $3,188(12)$ & $9,644(20)$ & $680(10)$ & 2,057 (19) \\
\hline Georgia & $3,024(13)$ & 13,904 (14) & $404(26)$ & $1,856(23)$ \\
\hline Florida & $2,760(14)$ & $26,438(7)$ & $188(44)$ & $1,801(26)$ \\
\hline New Jersey & $2,759(15)$ & $15,833(12)$ & $342(33)$ & $1,965(21)$ \\
\hline Michigan & $2,754(16)$ & $33,886(4)$ & $282(37)$ & $3,465(4)$ \\
\hline Virginia & 2,555 (17) & 12,322 (16) & $379(29)$ & $1,829(24)$ \\
\hline Louisiana & 2,545 (18) & 10,996 (17) & 585 (12) & 2,526 (10) \\
\hline Colorado & 2,066 (19) & $5,470(28)$ & $531(16)$ & 1,405 (34) \\
\hline Indiana & $2,036(20)$ & 12,979 (15) & 347 (32) & 2,213 (15) \\
\hline Wisconsin & $2,018(21)$ & $10,587(18)$ & $388(27)$ & $2,035(20)$ \\
\hline Tennessee & $1,797(22)$ & 9,783 (19) & 334 (34) & $1,821(25)$ \\
\hline Connecticut & $1,715(23)$ & 7,325 (24) & 525 (17) & 2,242 (14) \\
\hline New Mexico & $1,518(24)$ & $1,866(38)$ & $881(8)$ & $1,082(41)$ \\
\hline Kentucky & $1,419(25)$ & $8,276(23)$ & 363 (31) & 2,116 (18) \\
\hline South Carolina & $1,375(26)$ & $8,291(22)$ & $363(30)$ & 2,189 (16) \\
\hline Kansas & $1,345(27)$ & $4,490(30)$ & 517 (19) & $1,726(27)$ \\
\hline Maryland & $1,334(28)$ & $5,774(27)$ & $262(40)$ & 1,133 (39) \\
\hline Alabama & $1,247(29)$ & $6,201(26)$ & $288(36)$ & $1,435(32)$ \\
\hline lowa & $1,097(30)$ & $5,344(29)$ & $384(28)$ & $1,872(22)$ \\
\hline Utah & $984(31)$ & $3,204(32)$ & $477(20)$ & $1,552(29)$ \\
\hline Missouri & $977(32)$ & $7,081(25)$ & $181(46)$ & 1,309 (36) \\
\hline Vermont & $960(33)$ & 4,129 (31) & $1,632(2)$ & 7,015 (1) \\
\hline Nebraska & 957 (34) & $2,110(37)$ & $577(13)$ & $1,274(37)$ \\
\hline Idaho & $800(35)$ & 1,744 (39) & $661(11)$ & $1,443(31)$ \\
\hline Alaska & $760(36)$ & $1,024(44)$ & $1,246(6)$ & $1,680(28)$ \\
\hline Maine & 707 (37) & $1,704(40)$ & $569(14)$ & 1,372 (35) \\
\hline Oklahoma & 705 (38) & $2,968(33)$ & 212 (43) & $894(45)$ \\
\hline Arkansas & $685(39)$ & $2,484(35)$ & 271 (39) & 985 (43) \\
\hline Mississippi & $461(40)$ & 2,642 (34) & 169 (48) & 967 (44) \\
\hline West Virginia & $459(41)$ & $1,563(42)$ & $253(41)$ & $861(47)$ \\
\hline New Hampshire & $328(42)$ & $1,665(41)$ & $280(38)$ & $1,420(33)$ \\
\hline Delaware & $316(43)$ & $2,233(36)$ & $430(23)$ & $3,037(7)$ \\
\hline Wyoming & $269(44)$ & $576(47)$ & $561(15)$ & $1,200(38)$ \\
\hline District of Columbia & $244(45)$ & $468(49)$ & $460(21)$ & $884(46)$ \\
\hline Rhode Island & $240(46)$ & $1,034(43)$ & $243(42)$ & $1,047(42)$ \\
\hline Hawaii & $219(47)$ & $288(51)$ & $184(45)$ & $242(51)$ \\
\hline Nevada & $164(48)$ & $936(45)$ & $98(49)$ & $557(49)$ \\
\hline South Dakota & $126(49)$ & $504(48)$ & $171(47)$ & $683(48)$ \\
\hline Montana & $70(50)$ & $393(50)$ & $80(50)$ & $448(50)$ \\
\hline North Dakota & $35(51)$ & $713(46)$ & $54(51)$ & $1,113(40)$ \\
\hline
\end{tabular}


rate effects. ${ }^{4}$ While most of this article focuses on the effect of the trade channel on state manufacturing sectors, we attempt to provide some understanding of the relative importance of this effect. To do so, we examine both the strength of the trade shock and a measure of the indirect effects (oil prices) as determinants of state manufacturing employment growth. This analysis provides a rough estimate of the extent to which the indirect effects of the Asian crisis may have offset the direct effects of the crisis.

\section{STATE MANUFACTURING EXPORTS TO EAST ASIA}

Across states, the levels of manufacturing exports to all countries and manufacturing exports to East Asia vary substantially. ${ }^{5}$ During 1997, California was the leading state with manufacturing exports totaling $\$ 104.7$ billion, while Hawaii had the smallest amount of manufacturing exports- $\$ 0.29$ billion as shown in Table $1{ }^{6}$ Cal ifornia also was the state with the largest amount of manufacturing exports to East Asia$\$ 49.3$ billion. North Dakota had the smallest amount of manufacturing exports to East Asia- $\$ 0.04$ billion.

Because larger states tend to have higher levels of manufacturing exports, we also have presented manufacturing exports on a per-capita basis in Table 1. On this basis, Vermont, Washington, Texas, Michigan, and California were the five leading states. All of these five states, except Vermont, al so are among the top five exporting states on a gross-dollar basis. Substantial differences exist on a per-capita basis between the 10 largest exporters and the 10 smallest exporters. The average per-capita value of the 10 largest exporting states was $\$ 3,772$, while the average of the 10 smallest exporters was $\$ 757$.

Turning to per-capita exports to East Asia, Washington, Vermont, California, Arizona, and Oregon were the five leading states. Washington, California, and Arizona were among the top five states in exports to East Asia on a gross-dollar basis. Oregon was in the top 10, but Vermont was much further down the list. Once again, substantial differences exist between the 10 largest and 10 smallest exporters. The average per-capita value of the 10 largest exporters to East Asia was $\$ 1,286$, while the average of the 10 smallest exporters was $\$ 158$.

In light of the national decline in exports to East Asia from 1997 to 1998, it is not surprising that the exports of most states declined, as shown in Table 2. Ten of the 51 states (the District of Columbia is treated as a state in this paper) experienced a rise in exports to East Asia, while the remaining 41 states experienced declines. Thirty-one of these latter states had double-digit percentage declines in exports to East Asia. Eight states-Alaska, Arizona, the District of Columbia, Maryland, Montana, Nevada, North Dakota, and Vermont-saw their exports fall by more than 30 percent.

Examining state worldwide manufacturing exports provides additional perspective on the Asian trade shock. While only 10 of 51 states experienced a rise in exports of manufactured goods to East Asia, 26 states saw their worldwide exports of manufactured goods rise. Nevertheless, there is a high positive correlation between the changes in a state's manufacturing exports to East Asia and the changes in its worldwide manufacturing exports. ${ }^{7}$ All 10 states with rising manufacturing exports to East Asia were among the 26 states whose worldwide manufacturing exports rose, while 25 of the 41 states whose manufacturing exports to East Asia fell, also saw a decline in worldwide manufacturing exports.

\section{THE ASIAN CRISIS TRADE SHOCK AND STATE MANUFACTURING OUTPUT}

The effect of the Asian trade shock on an individual state can be separated into two factors: 1 ) the change in manufacturing exports to East Asia and 2) the importance of those exports to the state's economy. As shown in Table 2, 10 states increased their manufacturing exports to East Asia during 1998. These states, especially the five states with double-digit increases, appear to have been immune to the Asian crisis. ${ }^{8}$ Turning to the states whose manufacturing exports to East Asia fell during 1998, the declines ranged from 0.7 percent in Arkansas to 56.7 percent in Montana. Despite being suggestive, these data are not sufficient to conclude that the economy

\footnotetext{
${ }^{4}$ See Noland et al. (1998) and McKibbin (1998) for discussions of general equilibrium models and estimates indicating negligible macroeconomic effects.

5 See the appendix for a discussion of the state export data as well as all other data used in our study.

${ }^{6}$ We use 1997 as the reference year for comparing exports across states because the 1998 comparisons are affected by the Asian crisis.

7 The correlation coefficient is 0.76 .

8 The increase in these states' exports to East Asia does not mean that they did not suffer trade effects from the Asian crisis. It is possible that the increases in exports during 1998 were below what would have occurred in the absence of the crisis. To examine such a hypothesis one needs to know the trend in exports to East Asia from these states. Unfortunately, the MISER data prior to 1996 are not comparable with the more recent data, making it difficult to calculate a trend.
} 


\section{Table 2}

\section{Change in Real State Exports of Manufactured Goods \\ (Percent change 1997-98)}

\begin{tabular}{|c|c|c|}
\hline State & East Asia & All Countries \\
\hline Maine & 22.4 & 10.3 \\
\hline Rhode Island & 22.1 & 7.5 \\
\hline New Hampshire & 19.1 & 11.2 \\
\hline New Mexico & 15.4 & 9.7 \\
\hline Washington & 14.8 & 24.0 \\
\hline Louisiana & 6.9 & 2.1 \\
\hline Oregon & 5.1 & 4.9 \\
\hline Colorado & 0.8 & 4.9 \\
\hline New Jersey & 0.8 & 5.5 \\
\hline Florida & 0.5 & 6.5 \\
\hline Arkansas & -0.7 & 2.1 \\
\hline Virginia & -4.2 & 0.4 \\
\hline Nebraska & -4.9 & 4.5 \\
\hline Tennessee & -5.2 & 4.0 \\
\hline Pennsylvania & -5.8 & -0.2 \\
\hline Kansas & -6.9 & -3.7 \\
\hline Illinois & -7.7 & 11.5 \\
\hline Indiana & -8.5 & 3.9 \\
\hline North Carolina & -9.6 & -4.3 \\
\hline Idaho & -9.8 & -7.0 \\
\hline Connecticut & -10.4 & 6.1 \\
\hline Georgia & -10.5 & 3.9 \\
\hline Minnesota & -10.9 & -2.4 \\
\hline Massachusetts & -12.0 & -2.2 \\
\hline Missouri & -12.7 & -10.9 \\
\hline Delaware & -14.4 & 7.0 \\
\hline lowa & -15.0 & -0.4 \\
\hline Texas & -15.5 & 6.6 \\
\hline South Carolina & -16.4 & 4.2 \\
\hline New York & -16.6 & -0.1 \\
\hline Alabama & -16.7 & 8.1 \\
\hline West Virginia & -17.4 & -2.8 \\
\hline California & -18.5 & -1.6 \\
\hline Oklahoma & -19.2 & 1.3 \\
\hline Utah & -19.4 & 5.2 \\
\hline Wisconsin & -19.9 & -3.5 \\
\hline Michigan & -20.0 & -8.6 \\
\hline Kentucky & -22.2 & 2.7 \\
\hline Wyoming & -24.8 & -8.0 \\
\hline Hawaii & -25.6 & -16.4 \\
\hline Ohio & -27.9 & 1.4 \\
\hline Mississippi & -28.4 & -7.7 \\
\hline South Dakota & -29.6 & -13.7 \\
\hline Arizona & -30.7 & -16.7 \\
\hline Nevada & -33.0 & -23.7 \\
\hline Vermont & -36.5 & -0.7 \\
\hline Maryland & -40.1 & -10.6 \\
\hline North Dakota & -40.5 & -5.5 \\
\hline Alaska & -41.6 & -33.2 \\
\hline District of Columbia & -46.5 & -29.3 \\
\hline Montana & -56.7 & -17.6 \\
\hline
\end{tabular}

of Montana was affected more severely by this trade shock than the economy of Arkansas. To determine how these declines in exports affect a state's economy, one must look at the importance of these exports to output.

One clue to the importance of East Asian exports for a state is the share of that state's exports going to the region. As shown in Table 3, the geographic pattern of trade varies across states. During 1997, East Asia was the destination for 81 percent of New Mexico's manufacturing exports. Alaska and Hawaii also were highly dependent on the East Asian markets as both sent about 75 percent of their manufacturing exports to the East Asian countries. The other states bordering the Pacific Ocean-Oregon, California, and Washington-also sent a sizeable share of their manufacturing exports to East Asia. In contrast, only 5 percent of the manufacturing exports of North Dakota were shipped to East Asia. As a general statement, states in the western United States tend to ship a higher percentage of the manufacturing exports to East Asia than eastern states, as shown in Figure 1. One notable exception is the District of Columbia, which sent over 50 percent of its manufacturing exports to East Asia during 1997.

A more precise measure of how important the East Asian markets are to a state is given by a state's manufacturing exports to the region as a share of its manufacturing output. Using this measure, Alaska's manufacturing sector was the most dependent on East Asia-one-quarter of its manufactured shipments were sent to this region. ${ }^{9}$ In contrast, less than 1 percent of manufactured shipments from firms in North Dakota were sent to East Asia. Thus, if exports to East Asia fell by the same amount in Alaska and North Dakota, the effect on the Alaskan economy would be 25 times greater. The data in Table 4, as in Table 3, indicate the relative dependence of western states on the East Asian markets.

Multiplying a state's change in manufacturing exports to East Asia (Table 2) by the share of those exports in manufacturing shipments (Table 4) provides an estimate of the trade effect of the Asian crisis on a state's economy as shown in Table 5. More precisely, the data in Table 5 indicate the

\footnotetext{
${ }^{9}$ A better measure of the effect of the change in exports on a state's economy would be the share of exports in a state's gross product. A state's exports are measured, however, by the total dollar value of the shipments while gross state product is based on value added.
} 


\section{Figure 1}

\section{The Importance of East Asia for a State's} Manufacturing Exports 1997

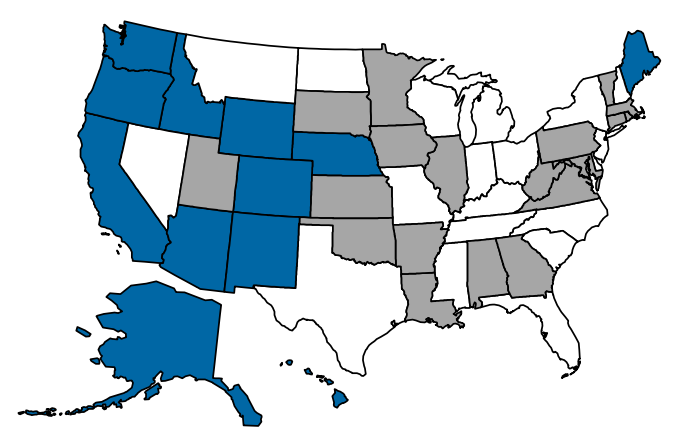

$35 \%$ and greater

Between $\mathbf{2 0} \%$ and $\mathbf{3 5} \%$

$20 \%$ or less

contribution of manufactured exports to East

Asia to a state's manufacturing sector growth rate during 1998. For example, the 26-percent decline in Hawaii's exports to East Asia reduced the growth rate of manufacturing output in that state by 1.5 percentage points. While these estimates indicate that the East Asian trade shock reduced the growth rate of manufacturing output by less than 0.3 percentage points in most states, they also indicate the diversity of effects across states even if one considers only those states whose exports to East Asia fell.

The data in Table 5 do not measure the overall change in manufacturing output in the states during 1998. Rather, these data denote the contribution of exports to the growth rate of manufacturing output. For example, the 19-percent decline in Utah's exports to East Asia (Table 2 ) reduced the growth rate of manufacturing output in that state by 1 percentage point (Table 5). It is possible, however, that this decrease in exports to East Asia was offset by either an increase in exports to other foreign markets or an increase in domestic sales. Overall, Utah's manufacturing sector may have experienced no decline in growth, depending on the strength of demand in these other markets. The data in Table 2 indicate that for most states a decline in exports to East Asia was not offset by a rise in exports to other regions. Whether domestic demand was strong enough to overcome the trade effect will not be known until the 1998 shipments data are released in late 2000.

\section{Table 3}

\section{East Asia's Share of Real State Exports of Manufactured Goods (1997)}

State

Percent Share

\begin{tabular}{lc}
\hline New Mexico & 81.4 \\
Hawaii & 76.0 \\
Alaska & 74.2 \\
District of Columbia & 52.1 \\
Oregon & 49.3 \\
California & 47.1 \\
Wyoming & 46.8 \\
Idaho & 45.9 \\
Nebraska & 45.3 \\
Washington & 45.1 \\
Arizona & 43.8 \\
Maine & 41.5 \\
Colorado & 37.8 \\
Minnesota & 33.1 \\
Massachusetts & 30.9 \\
Utah & 30.7 \\
Kansas & 30.0 \\
West Virginia & 29.4 \\
Arkansas & 27.6 \\
South Dakota & 25.0 \\
Oklahoma & 23.7 \\
Connecticut & 23.4 \\
Vermont & 23.3 \\
Rhode Island & 23.2 \\
Louisiana & 23.1 \\
Maryland & 23.1 \\
Illinois & 21.9 \\
Georgia & 21.7 \\
Pennsylvania & 21.6 \\
Virginia & 20.7 \\
lowa & 20.5 \\
Alabama & 20.1 \\
New York & 19.8 \\
New Hampshire & 19.7 \\
North Carolina & 19.2 \\
Texas & 19.1 \\
Wisconsin & 19.1 \\
Tennessee & 18.4 \\
Montana & 17.8 \\
Ohio & 17.7 \\
Nevada & 17.5 \\
Mississippi & 17.4 \\
New Jersey & 17.4 \\
Kentucky & 17.1 \\
South Carolina & 16.6 \\
Indiana & 15.7 \\
Delaware & 14.2 \\
Missouri & 13.8 \\
Florida & 10.4 \\
Michigan & \\
North Dakota & \\
\hline
\end{tabular}




\section{Table 4}

\section{Manufacturing Exports to East Asia as a Share of Manufactured Shipments (1996)}

\begin{tabular}{|c|c|}
\hline State & Export-Shipment Ratio \\
\hline Alaska & 25.0 \\
\hline Washington & 17.3 \\
\hline California & 13.4 \\
\hline Arizona & 12.7 \\
\hline Oregon & 8.8 \\
\hline Wyoming & 8.4 \\
\hline Hawaii & 5.9 \\
\hline Utah & 5.6 \\
\hline Massachusetts & 5.3 \\
\hline Colorado & 4.9 \\
\hline Texas & 4.6 \\
\hline Idaho & 4.6 \\
\hline New York & 4.3 \\
\hline New Mexico & 4.2 \\
\hline Vermont & 4.1 \\
\hline Maryland & 3.9 \\
\hline Minnesota & 3.9 \\
\hline Nebraska & 3.8 \\
\hline Illinois & 3.3 \\
\hline District of Columbia & 3.3 \\
\hline Florida & 3.2 \\
\hline Connecticut & 3.1 \\
\hline Louisiana & 2.9 \\
\hline Virginia & 2.9 \\
\hline New Jersey & 2.8 \\
\hline Kansas & 2.7 \\
\hline Maine & 2.7 \\
\hline Georgia & 2.6 \\
\hline West Virginia & 2.6 \\
\hline South Carolina & 2.2 \\
\hline Nevada & 2.2 \\
\hline Ohio & 2.1 \\
\hline Rhode Island & 2.0 \\
\hline Alabama & 2.0 \\
\hline Pennsylvania & 1.9 \\
\hline lowa & 1.9 \\
\hline New Hampshire & 1.9 \\
\hline North Carolina & 1.8 \\
\hline Oklahoma & 1.8 \\
\hline Tennessee & 1.8 \\
\hline Wisconsin & 1.6 \\
\hline Delaware & 1.5 \\
\hline Indiana & 1.5 \\
\hline Kentucky & 1.5 \\
\hline Arkansas & 1.4 \\
\hline Michigan & 1.4 \\
\hline Montana & 1.2 \\
\hline South Dakota & 1.0 \\
\hline Missouri & 0.9 \\
\hline Mississippi & 0.9 \\
\hline North Dakota & 0.6 \\
\hline
\end{tabular}

\section{A CLOSER LOOK AT THE STATE EFFECTS}

\section{Country Detail}

Examining the change in state manufacturing exports to each country in East Asia, rather than to the region as a whole, may provide some insight into the different effects across states. At first glance, differences in the states' trading partners do not appear to explain the variations in effects across states. First, exports declined to nearly all countries in the region, as underscored by the data in Table 6. Only three states-Maine, New Hampshire, and Washington-experienced declines in exports to fewer than half of the East Asian countries. Not surprisingly, these three states were among those whose exports to East Asia rose during 1998. In contrast, most states had export declines to at least seven of the 10 East Asian countries. Four-Maryland, Montana, North Carolina, and Ohio-had declines in exports to all 10 countries. As Table 2 shows, these states, except for North Carolina, had export declines of 25 percent or more to the region.

Second, across states, the major trading partners in East Asia do not vary substantially. Japan is the most important export destination in East Asia for most states, and South Korea is an important export market for many. As a result, declines in exports to these two countries typically accounted for a large share of a state's overall decline in exports to East Asia in 1998.

Nevertheless, for some states, trading partners mattered. The economy of Thailand, for example, suffered one of the most severe contractions in the region with output falling by 8 percent during 1998. Thailand was not an important export market for most states, but it was for the District of Columbia and Minnesota. In 1997, 48 percent of D.C.'s exports of manufactured goods to East Asia went to Thailand. In 1998, D.C.'s exports to Thailand fell by 97 percent, accounting for nearly all of the 47 percent decline in its exports of manufactured goods to East Asia. Meanwhile, Thailand accounted for 13 percent of Minnesota's manufacturing exports to East Asia during 1997. These exports fell by half in 1998, accounting for 60 percent of Minnesota's overall decline in manufacturing exports to East Asia. On the other hand, China's economy remained relatively robust during the crisis. China is not a major export destination for many states; however, Louisiana sent over 20 percent of its 1997 East Asian exports to China. A rise in these exports during 1998 accounted for the 
overall increase in Louisiana's exports to the region.

\section{Industry Detail}

Disaggregating the manufacturing data from the one-digit SIC level to the two-digit SIC level also provides some insight into the different experiences of the states during 1998. The chemical and allied products (SIC 28), industrial machinery and equipment (SIC 35), and electronic and electrical products (SIC 36) industries represented the highest shares of manufacturing exports to East Asia across the broadest range of states. Each of these industries accounted for more than 10 percent of manufacturing exports to East Asia in more than half of the states. Food and kindred products (SIC 20), transportation equipment (SIC 37), and instruments and related products (SIC 38) also were important industries for a number of states exporting to East Asia. The importance of individual manufacturing industries for exports varies across states, more so than the destination of these exports, as discussed above

The manufacturing exports of some states are concentrated in a single industry. The electronic and electrical products industry, for example, accounted for 96 percent of New Mexico's manufacturing exports to East Asia during 1997, while chemicals and allied products accounted for 99 percent of Wyoming's exports to the region. A sharp drop in Wyoming's chemical exports to East Asia, in conjunction with the relative importance of these markets for the state industry, was responsible for most of the negative effect on the manufacturing sector noted in Table 5. Wyoming's experience is in contrast with that of Washington. During 1997, 64 percent of Washington's manufactured exports to East Asia were transportation equipment, mostly aircraft. Sales of aircraft to East Asia, particularly China and Taiwan, increased sharply during 1998. These increases primarily are responsible for the increase in Washington's manufacturing exports to East Asia. ${ }^{10}$

The manufacturing exports of other states were more diversified. For example, none of the 20 industries accounted for more than 20 percent of the exports to East Asia from either Missouri, North Car-

\footnotetext{
${ }^{10}$ It is likely that the increase in aircraft exports accounts for most of the positive export boost in Washington's manufacturing sector during 1998, listed in Table 5. Manufacturing shipments for Washington's transportation industry are not disclosed by the Department of Commerce, however, to prevent disclosure of data relevant to one company.
}

\section{Table 5}

\section{The Effect of the Trade Shock on Manufacturing Output Growth}

\begin{tabular}{|c|c|}
\hline State & Percent \\
\hline Washington & 2.56 \\
\hline New Mexico & 0.65 \\
\hline Maine & 0.60 \\
\hline Oregon & 0.45 \\
\hline Rhode Island & 0.44 \\
\hline New Hampshire & 0.36 \\
\hline Louisiana & 0.20 \\
\hline Colorado & 0.04 \\
\hline New Jersey & 0.02 \\
\hline Florida & 0.02 \\
\hline Arkansas & -0.01 \\
\hline Tennessee & -0.09 \\
\hline Pennsylvania & -0.11 \\
\hline Missouri & -0.12 \\
\hline Virginia & -0.12 \\
\hline Indiana & -0.13 \\
\hline North Carolina & -0.18 \\
\hline Kansas & -0.19 \\
\hline Nebraska & -0.19 \\
\hline Delaware & -0.22 \\
\hline North Dakota & -0.25 \\
\hline Illinois & -0.26 \\
\hline Mississippi & -0.26 \\
\hline Michigan & -0.27 \\
\hline Georgía & -0.28 \\
\hline lowa & -0.28 \\
\hline South Dakota & -0.31 \\
\hline Connecticut & -0.32 \\
\hline Alabama & -0.33 \\
\hline Wisconsin & -0.33 \\
\hline Kentucky & -0.33 \\
\hline Oklahoma & -0.35 \\
\hline South Carolina & -0.37 \\
\hline Minnesota & -0.42 \\
\hline Idaho & -0.45 \\
\hline West Virginia & -0.45 \\
\hline Ohio & -0.59 \\
\hline Massachusetts & -0.63 \\
\hline Montana & -0.71 \\
\hline New York & -0.71 \\
\hline Nevada & -0.72 \\
\hline Texas & -0.72 \\
\hline Utah & -1.08 \\
\hline Vermont & -1.51 \\
\hline Hawaii & -1.51 \\
\hline District of Columbia & -1.54 \\
\hline Maryland & -1.58 \\
\hline Wyoming & -2.07 \\
\hline California & -2.48 \\
\hline Arizona & -3.91 \\
\hline Alaska & -10.40 \\
\hline Unweighted average & -0.62 \\
\hline
\end{tabular}




\section{Table 6}

\section{Declining Exports to East Asia on a Country Basis (1998)}

\begin{tabular}{|c|c|}
\hline State & Number \\
\hline Alaska & 8 \\
\hline Alabama & 7 \\
\hline Arkansas & 7 \\
\hline Arizona & 7 \\
\hline California & 9 \\
\hline Colorado & 6 \\
\hline Connecticut & 8 \\
\hline District of Columbia & 8 \\
\hline Delaware & 7 \\
\hline Florida & 6 \\
\hline Georgia & 9 \\
\hline Hawaii & 7 \\
\hline lowa & 8 \\
\hline Idaho & 7 \\
\hline Illinois & 8 \\
\hline Indiana & 9 \\
\hline Kansas & 8 \\
\hline Kentucky & 7 \\
\hline Louisiana & 7 \\
\hline Massachusetts & 7 \\
\hline Maryland & 10 \\
\hline Maine & 3 \\
\hline Michigan & 9 \\
\hline Minnesota & 5 \\
\hline Missouri & 6 \\
\hline Mississippi & 9 \\
\hline Montana & 10 \\
\hline North Carolina & 10 \\
\hline North Dakota & 9 \\
\hline Nebraska & 5 \\
\hline New Hampshire & 3 \\
\hline New Jersey & 7 \\
\hline New Mexico & 7 \\
\hline Nevada & 8 \\
\hline New York & 6 \\
\hline Ohio & 10 \\
\hline Oklahoma & 7 \\
\hline Oregon & 6 \\
\hline Pennsylvania & 7 \\
\hline Rhode Island & 5 \\
\hline South Carolina & 9 \\
\hline South Dakota & 6 \\
\hline Tennessee & 7 \\
\hline Texas & 8 \\
\hline Utah & 7 \\
\hline Virginia & 7 \\
\hline Vermont & 6 \\
\hline Washington & 4 \\
\hline Wisconsin & 9 \\
\hline West Virginia & 9 \\
\hline Wyoming & 8 \\
\hline
\end{tabular}

olina, or Nevada. Exports declined across a broad range of the industries in all of these states.

\section{THE ASIAN TRADE SHOCK AND STATE MANUFACTURING EMPLOYMENT}

The results in Table 5 indicate that the manufacturing sector in some states was subjected to large, negative shocks, while many other states were affected only slightly. We use regression analysis to assess the importance of these trade effects on state manufacturing employment growth. Of course, the estimated trade effects were not the only influence on employment growth across states during 1998. Consequently, additional variables are required for the regression analysis. We use two additional variables, one of which is related to the Asian crisis. Commodity prices fell during 1998 partly as a result of decreased demand in East Asia. Perhaps most important was the fall in the price of oil. Those states with a high concentration of manufacturing industries that use petroleum products extensively as an input would benefit relative to states that produce petroleum and its related products. Employment trends across states, which reflect the interaction of various other economic factors affecting manufacturing employment, also are likely to be important. For example, states where manufacturing employment growth has been falling recently may be those states with industries shedding employment to remain competitive. Hence, employment changes are occurring regardless of the strength of the Asian economies.

In sum, we can think of state-level manufacturing employment growth during 1998 as being determined by previous employment growth and two shocks: the Asian trade shock, which was unfavorable to employment growth in most states; and the oil price shock, which was favorable to employment growth in most states. These relationships can be summarized by the following equation:

$$
\begin{aligned}
\text { megt }_{\mathrm{i}} & =\beta_{0}+\beta_{1} * \text { trade }_{\mathrm{i}}+\beta_{2} * \text { oil }_{\mathrm{i}} \\
& +\beta_{3} * \text { megtrend }_{\mathrm{i}}+\epsilon_{\mathrm{i}}
\end{aligned}
$$

where the subscript i refers to individual states, megt is the manufacturing employment growth rate in each state, trade is the negative of the estimated trade effect on the manufacturing sector in each state (given in Table 5), oil is an estimate of the differential effect of a decline in oil prices on each state (see the appendix), megtrend is the average annual growth rate of manufacturing employment from 1994 to 
1997, and $\epsilon$ is an error term. The betas indicate the effect of each of these variables on manufacturing employment growth.

We expect $\beta_{1}<0$, and $\beta_{2}$ and $\beta_{3}>0$. First, a larger Asian trade shock should result in a larger decline in manufacturing employment growth. Specifically, states such as Arizona and Alaska should experience larger declines in manufacturing employment growth than Arkansas or Tennessee Second, a drop in the price of oil should raise manufacturing employment growth in energy-importing states. In other words, states with industry compositions weighted toward users rather than producers of energy should experience larger increases in employment growth than others. Finally, states that have experienced recent increases in manufacturing employment are likely to continue to do so.

Our estimation of equation 1 produced the following results:

$$
\begin{aligned}
\text { megt }= & 0.23-0.03 * \text { trade }+1.93 * \text { oil } \\
& (0.99)(-0.24) \\
& +0.57 * \text { megtrend }
\end{aligned}
$$

where the t-statistics are given in parentheses. ${ }^{11}$ These results indicate that the Asian trade shock had a negative, but statistically insignificant, effect on employment growth across states. That is, based on the regression analysis, the Asian trade shock was not a factor driving differences in state-level manufacturing employment growth during 1998. Meanwhile, we find the oil price shock to have a positive, statistically significant effect on manufacturing employment growth. Thus, statistically speaking, the differential effect of the Asian crisis on state employment may be more pronounced through its effect on oil prices than through trade flows. Finally, prior manufacturing employment growth was found to have a positive, statistically significant effect on current (1998) manufacturing employment growth. ${ }^{12}$

Our results leave an important question unanswered: Why didn't the trade effect have a noticeable effect on manufacturing employment across states? One possibility is that the differential shocks were not large enough to generate statistically significant differences in employment growth. Despite much variation across states in their percentage declines of exports to East Asia, and the importance of East Asia as an export destination, there is little difference across many states in the estimated trade shock. More than two-thirds of the estimates for the individual states are between 0.04 percent and -0.72 percent, a range of only 0.76 percentage points.
Another possibility is that our measure of the trade shock, because it relies on shipments data (both for exports and output) rather than value-added data, is deficient. Employment changes in a state are likely to be related to a state's value-added changes; however, the shipments data might be a poor measure of the production that occurred in a specific state, and thus, are not directly related to employment.

\section{CONCLUSION}

The Asian crisis resulted in a decline in most states' exports to East Asia, but the severity of the decline varied across states. An assessment of the importance of the decline in exports for a state's economy depends on the extent of the decline and the importance of the East Asian markets for the state. In general, the western states were more dependent on the East Asian markets, and hence, were the hardest hit by the trade shock. Of the states in which the decline in exports to East Asia lowered the growth rate of manufacturing output by more than 1 percent, two-thirds were western states. Some western states, most notably Washington, however, were among those states whose exports to East Asia rose despite the crisis.

Using these estimates of the trade shock's effect on each state's manufacturing sector, we tested the statistical relevance of the trade shock to explain changes in a state's manufacturing employment during 1998. We found that the trade shock did not explain differences in the employment experiences of states during 1998. A factor that was statistically relevant was the effect of the change in the price of oil on a state's economy. Thus, taking our results at face value, the differential state employment effects that resulted from the trade changes of the Asian crisis mattered little. A stronger case can be made that the oil price declines during late 1997 and 1998, some portion of which can be attributed to the Asian crisis, were more important than the trade effects in affecting manufacturing employment at the state level.

\footnotetext{
${ }^{11}$ The $\overline{\mathrm{R}}^{2}$ for the equation is .45.

${ }^{12}$ To investigate whether the Asian crisis affected state employment in specific industries, we estimated equation 1 for manufacturing industries at the two-digit level. Unfortunately, data limitations affected this effort. Only 14 of the $20 \mathrm{SIC}$ industries had complete data for at least half of the states. For 11 of the 14 industries, the results were similar to those for manufacturing as a whole - the Asian trade effect, even though exhibiting the anticipated negative sign, was statistically insignificant. Results for the employment effect of the oil price shock also were not strong as the effect was statistically insignificant in 12 of the 14 industries.
} 


\section{REFERENCES}

Brown, Stephen P.A., and Mine K. Yücel. “Energy Prices and State Economic Performance," Federal Reserve Bank of Dallas Economic Review (Second Quarter 1995), pp. 13-23.

Coughlin, Cletus C., and Thomas B. Mandelbaum. "Measuring State Exports: Is There a Better Way?" this Review (July/August 1991), pp. 65-79.

Cronovich, Ron, and Ricardo Gazel. "How Reliable Are the MISER Foreign Trade Data?" unpublished manuscript, May 1999.

Duca, John V., David M. Gould, and Lori L. Taylor. "What Does the Asian Crisis Mean for the U.S. Economy?" Federal Reserve Bank of Dallas Southwest Economy (March/April 1998), pp. 1-6.

Emmons, William R., and Frank A. Schmid. "The Asian Crisis and the Exposure of Large U.S. Firms," this Review (January/February 2000). pp. 15-34.

Gazel, Ricardo C., and Russell L. Lamb. "Will the Tenth District Catch the Asian Flu?" Federal Reserve Bank of Kansas City Economic Review (Second Quarter 1998), pp. 9-26.

McKibbin, Warwick. The Crisis in Asia: An Empirical Assessment, Brookings Discussion Paper in International Economics No. 136, 1998.

Noland, Marcus, Li-Gang Liu, Sherman Robinson, and Zhi Wang. Global Economic Effects of the Asian Currency Devaluations, Institute for International Economics, 1998.

Pollard, Patricia S., and Cletus C. Coughlin. "Going Down: The Asian Crisis and U.S. Exports," this Review (March/April 1999), pp. 33-45.

U.S. Department of Commerce and U.S. Department of Treasury. Treasury and Commerce Release Analysis Showing Impact of Asian Crisis on Individual States, March 24, 1998.

Valletta, Rob. “East Asia's Impact on Twelfth District Exports," Federal Reserve Bank of San Francisco Economic Letter (November 20, 1998).
Appendix-Data Sources

\section{State Export Data}

The data on state manufacturing exports used in this study are produced by the Massachusetts Institute for Social and Economic Research (MISER) at the University of Massachusetts. These data are export shipments by the state of origin of movement. The source of the data is the Shipper's Export Declaration (SED). This document identifies "the state where the product began its journey to point of export." The Census Bureau collects these data, which are adjusted by MISER to fill in missing industry and state information.

The MISER export data have their weaknesses. The identified export state may not be the state of manufacture, but rather the state of a broker (or wholesaler) or the state where a number of shipments were consolidated. This problem is more pronounced for exports of agricultural commodities than manufactured goods. Hence, our study focuses on manufactured goods.

An alternative to the export data based on the origin of movement is one based on exporter location. These data, which had been available since 1993, also are based on the Shipper's Export Declaration. Compared to the origin of movement series, the identified state of the exporter in these data more likely reflects the state of a broker or wholesaler, or the headquarters of companies, rather than the state of manufacture A potentially better source of state export data for identifying the state of production has been produced by the U.S. Census as part of the Annual Survey of Manufacturers; however, Exports from Manufacturing Establishments was discontinued after data for 1992 were published.

The data we used, despite their limitations, are regarded as the best available on state exports. ${ }^{1}$ They are available quarterly with a three-month lag. In addition to the state information, the data contain information on one-and two-digit industry (SIC) code, destination country, and dollar value and weight by method of transportation. ${ }^{2}$

\footnotetext{
${ }^{1}$ Additional discussion of the various issues involving state export data can be found in Coughlin and Mandel baum (1991) and Cronovich and Gazel (1999).

${ }^{2}$ Information on this database is available at $<$ www.umass.edu/miser/axes $>$.
} 


\section{Export Price Data}

Real exports were calculated by deflating the 1997 export data by the change in the price of exports be tween 1996 and 1997. The 1998 exports were deflated by the price change between 1996 and 1998. Export price data are available from the Bureau of Labor Statistics. These data are not available by SIC code. Thus, we started with an export price index that groups the data based on the Standard International Trade Classification (SITC) system and matched these industries with the appropriate SIC codes. When multiple SITC codes fit one SIC category, a weighted average of the price indices for those categories was constructed to arrive at the price index on an $\mathrm{SIC}$ basis. For more details see Pollard and Coughlin (1999).

\section{Per-Capita Exports}

Per-capita exports were calculated by dividing real exports for each state by the population of the state. The population data are available from the Census Bureau.

\section{Manufacturing Shipments Data}

To measure manufacturing output at the state level we use the value of industry shipments. These data are from the Annual Survey of Manufacturing conducted by the Census Bureau. The latest available data were for 1996.

\section{Employment Data}

The state level employment data came from the payroll employment survey conducted by the Bureau of Labor Statistics. We used the average annual employment data for 1997 and 1998 to calculate the growth rate in employment during 1998. The trend employment growth rate is calculated using the average annual growth rate in state employment between 1994 and 1997. Data at both the one-and two-digit industry (SIC) code were used in the regression analysis.

\section{Oil Price Effect Data}

The oil price effect data are based on estimates by Brown and Yücel (1995) of the effect of a 10-percent change in the price of oil on a state's nonagricultural employment. Declining energy prices should retard economic activity in energy-exporting states (i.e, those that produce more energy than they consume), and stimulate economic activity in energy-importing states. The paper contains estimates for 1992 and 2000. The results reported in this paper use the estimates for the year 2000, but the results are similar using the 1992 estimates. 
REVIEW

14 January/FEbruary 2000 